\title{
Pengabdian kolaboratif: Revitalisasi situs Kabuyutan Ciburuy sebagai desa wisata budaya dan pusat ekonomi kreatif
}

\author{
Muhamad Alim ${ }^{1}$
}

\begin{abstract}
Community service is a compulsory activity for academics in every Indonesian university since it is listed in the Tri Dharma Perguruan Tinggi. The student executive board is no exception as it collects and empowers students to implement their knowledge for the community. A community development program is conducted, combined with the potential of local culture and the needs of the community with the main purpose of solving economic and social problems. The program began in June 2019 and will continue to strive for its sustainability to make Pamalayan village, which is strategically located at the foot of Cikuray mountain, Garut district, a cultural tourism village and creative economy center. The method used is collaboration with the government, local entrepreneurs and communities, participatory training, textual discussions, and creative economy empowerment. The program has proven to play a role in the preservation of Sundanese cultures, such as ancient Sundanese manuscripts, Jaipong dance, and Pencak silat which will increase its appeal to tourists. The program is also influential in improving the standard of living of the Pamalayan villagers through the media of the creative economy based on local wisdom.
\end{abstract}

\section{Keywords}

Sustainability service, local culture, creative economy

\section{Pendahuluan}

Pembangunan pariwisata pada hakikatnya bertujuan untuk mensejahterakan masyarakat. Oleh karena itu, hasil pembangunan harus bisa dimanfaatkan oleh masyarakat, terutama di tempat dilakukannya pembangunan. Hal tersebut didasarkan pada hakikat pembangunan pariwisata sebagai media pembangunan dan pemberdayaan masyarakat yang dampaknya mampu menyentuh seluruh lapisan masyarakat (Utami, 2016). Termasuk pembangunan pariwisata di desa-desa yang mempunyai potensi alam, sosial dan budaya.

Dewasa ini, masyarakat metropolitan cenderung jenuh terhadap wisata modern. Mereka lebih tertarik untuk berwisata ke pedesaan yang mempunyai keindahan alam yang menjadi daya tarik wisatawan. Desa wisata merupakan kawasan yang menawarkan keindahan dan keaslian desa baik secara budaya, ekonomi dan kehidupan sosial masyarakat desa (Hadiwijoyo, 2012).

Desa wisata didorong oleh tiga faktor utama. Pertama, otentisitas potensi budaya masyarakat daripada di perkotaan, seperti tradisi, ritual dan topografi yang menjadi daya tarik. Kedua, keindahan dan keasrian alam yang tidak tercemar oleh polusi. Ketiga, lambatnya perkembangan ekonomi desa merupakan alasan rasional untuk memanfaatkan potensi sosial budaya masyarakat secara optimal agar dapat meningkatkan taraf hidup masyarakat (Hadiwijoyo, 2012).
Akan tetapi kurangnya pengetahuan masyarakat akan potensi yang sebenarnya dimiliki oleh kawasan wisata tersebut dapat menghambat segala bentuk inovasi yang memungkinkan dapat diterapkan untuk memajukan kawasan wisata. Selain itu, kurangnya kesadaran masyarakat akan pentingnya pelestarian kawasan wisata budaya serta kurangnya perhatian dari berbagai pihak semakin membuat kawasan wisata budaya tersebut tidak berkembang (Hadiwijoyo, 2012).

Salah satu potensi wisata budaya yang saat ini perlu mendapat perhatian ialah Desa Pamalayan, Kecamatan Bayongbong, Kabupaten Garut. Berdasarkan data dari profil Desa Pamalayan tahun 2019, secara umum Desa Pamalayan memiliki luas wilayah mencapai 296,143 Ha. Desa Pamalayan sendiri memiliki total $15 \mathrm{RW}$, dengan potensi terbesar ada dalam sektor pertanian. Sebanyak 67\% wilayah di Desa Pamalayan berfungsi sebagai lahan pertanian, sehingga sangat berkorelasi dengan jumlah masyarakat yang berprofesi sebagai petani.

Secara sosial budaya masyarakat desa Pamalayan merupakan suku Sunda dan beragama Islam. Hal ini dibuktikan dengan adanya Situs Kabuyutan Ciburuy yang merupakan

\footnotetext{
${ }^{1}$ Fakultas IImu Budaya, Universitas Padjadjaran
}

Korespondensi:

Muhamad Alim, Universitas Padjadjaran

Email: muhamad16023@mail.unpad.ac.id 
satu dari 73 warisan budaya kesundaan berbasis pendidikan yang dinamakan 'Mandala' di Indonesia (Erick Paulus, 2018). Situs Kabuyutan Ciburuy dikelola oleh satu keluarga yang kemudian disebut juru kunci, sehingga pengelolaannya secara turun temurun. Setiap hari Rabu minggu ketiga bulan Muharom sekitar pukul 19.30, selalu diadakan upacara Seba (Setiati, 2020). Selain itu di daerah Situs Kabuyutan Ciburuy terdapat tiga rumah adat yang bernama Bumi Padaleman yang merupakan tempat penyimpanan naskah-naskah kuno, daun lontar dan nipah, Bale Leuit tempat penyimpanan Padi yang terletak di pintu masuk situs dan Bale Patamon adalah tempat tinggal juru kunci dan tempat peletakan keramat seperti kris dan kujang (Rahmatulloh, 2019). Manuskrip kuno kesundaan yang terdapat di Bale Padelaman adalah 1270 lempir yang terdiri dari 27 Kropak (Sukaesih, 2016). Tingkat kesadaran dan pengetahuan masyarakat sekitar mengenai keberadaan, pengelolaan dan pengembangan potensi wisata budaya masih sangat rendah, sehingga Situs Kabuyutan Ciburuy yang mempunyai nilai historis, ekonomi dan kebudayaan yang tinggi tidak termanfaatkan dengan optimal. Banyaknya warga sekitar yang tidak mengetahui eksistensi situs kabuyutan ciburuy ini disebabkan oleh letak geografis situs yang di kaki gunung Cikuray. Peletakan situs yang berada di kaki gunung tersebut sesuai dengan konsep leluhur Sunda yang biasa menyimpan sesuatu yang dianggap suci di tempat yang lebih tinggi karena dinggap lebih dekat dengan Hyang (Tuhan) (Darsa, 2015). Kawasan kabuyutan Ciburuy juga memiliki kesenian Sunda berupa tari tradisional Jaipong dan kesenian Gong Renteng yang sempat berjaya dan menjadi kesenian khas masyarakat Desa Pamalayan tepatnya di sekitar kawasan situs tersebut.

Permasalahan yang dihadapi oleh desa Pamalayan, yaitu berkaitan dengan potensi kawasan wisata budaya yang belum optimal dalam pemanfaatan kawasan situs serta belum terbentuknya kesadaran seluruh pihak akan potensi yang muncul. Berdasarkan hasil observasi dan pengamatan, kondisi situs tersebut sebenarnya berada dalam kondisi baik, tetapi kawasan wisata budaya tersebut kurang menarik minat wisatawan karena kurangnya informasi yang dapat dihimpun mengenai situs ini baik secara luring ataupun daring.

Selain letaknya di kaki gunung Cikuray, rendahnya kesadaran untuk melestarikan kebudayaan tersebut disebabkan oleh tingkat pendidikan masyarakat Desa Pamalayan yang minim mengenyam pendidikan tinggi. Berdasarkan data desa Pamalayan tingkat pendidikan akhir masyarakat mayoritas adalah Sekolah Menengah Pertama (SMP). Hal tersebut kontraproduktif dengan rencana pemerintah. Minimnya kesadaran akan pendidikan juga disebabkan faktor ekonomi masyarakat yang bisa dikatakan belum memenuhi taraf hidup layak. Oleh karena itu, diharapkan melalui program desa wisata budaya dapat meningkatkan kesadaran akan pentingnya pendidikan.

Melihat berbagai potensi dan permasalahan tersebut, diharapkan melalui Program Revitalisasi Situs Kabuyutan Ciburuy Sebagai Desa Wisata dan Pusat Ekonomi Kreatif
Masyarakat, akan berkembang kesadaran masyarakat atas pentingnya kawasan wisata budaya dan budaya itu sendiri sehingga mendorong partisipasi aktif masyarakat dalam mengembangkan Desa Pamalayan menjadi kawasan wisata budaya berkelanjutan. Adapun untuk mencapai tujuan itu dilakukan pengembangan melalui pelatihan komprehensif, seperti pengajaran aksara Sunda dan pembuatan souvenir yang berukiran aksara sunda untuk mengembangkan kembali aksara sunda, serta diskusi naskah. Disamping itu dilakukan penghidupan kembali kesenian Gong Renteng, yang diharapkan juga dapat memperkuat Desa Pamalayan menjadi kawasan wisata yang memiliki manfaat sebagai sumber kesejahteraan bagi masyarakat Desa Pamalayan. Berdasarkan paparan di atas, kami berharap kerja sama dengan berbagai pihak (Penthahelix), baik pemerintah, akademisi, perusahaan, swasta, media dan masyarakat saling bahu membahu untuk berperan menjadi solusi dari permasalahan pemanfaatan wisata cagar budaya Situs Kabuyutan Ciburuy.

Jika diidentifikasi masalah yang merujuk pada Pokokpokok Pikiran Kebudayaan Daerah (PPKD) Garut, maka akan tampak beberapa persoalan masyarakat yang penting untuk diselesaikan. Pertama, potensi kawasan Situs Kabuyutan Ciburuy sebagai warisan budaya belum termanfaatkan dengan baik. Kedua, minimnya kesadaran masyarakat akan pentingnya Situs Kabuyutan Ciburuy sebagai kawasan wisata budaya. Ketiga, diperlukan pengelolaan sistem pengembangan informasi Situs Kabuyutan Ciburuy agar lebih publikatif, menarik dan terstruktur. Keempat, mengaktifkan kembali Pencak Silat dan Gong Renteng yang sudah punah tergerus arus globalisasi budaya luar. Terakhir, meningkatkan motivasi belajar kesenian anak-anak desa Pamalayan. Mengembangkan ekonomi masyarakat desa Pamalayan berbasis budaya lokal.

Pengabdian pada masyarakat ini diharapkan dapat menjadi bagiad dari proses penyelesaian berbagai permasalahan diatas dengan beberapa tindakan berikut. Pertama, mengembangkan potensi naskah kuno yang terdapat dalam kawasan Situs Kabuyutan Ciburuy untuk dimanfaatkan sebagai kawasan wisata budaya yang dapat memajukan pendidikan dan perekonomian bagi masyarakat Desa Pamalayan. Kedua, membangun kesadaran masyarakat akan potensi naskah dan budaya yang akan menjadi ciri khas dan identitas Kawasan Situs Ciburuy sebagai kawasan wisata budaya dengan mengadakan seminar kenaskahan dan pembelajaran aksara Sunda bagi anak-anak. Ketiga, penyebaran informasi berkaitan dengan Situs Kabuyutan Ciburuy dilakukan melalui pembuatan akun kerja Instagram@kabuyutan_ciburuy, pemberitaan media daring dan digitalisasi naskah.

Keempat, mengajarkan kembali kesenian Pencak Silat dan Gong Renteng kepada anak-anak agar masyarakat Desa Pamalayan memiliki identitas budaya yang lengkap serta menjadi daya tarik lain yang dimiliki kawasan Situs Kabuyutan Ciburuy. Kelima, pengajaran Aksara Sunda kepada anak-anak dengan metode pembelajaran kreatif dan 
simanar kenaskahan sebagai bagian dari pengembangan kawasan wisata budaya naskah sehingga naskah-naskah yang terdapat dalam situs dapat ditransliterasikan serta dapat disajikan isinya kepada masyarakat. Terakhir, pengadaan aksesoris situs, seperti kaos bertuliskan makna dan pembelajaran dari naskah kuno yang terdapat di situs.

Luaran yang diharapkan adalah menjadikan desa Pamalayan sebagai desa wisata penaskahan Sunda dan pengembangan ekonomi kreatif masyarakat.

\section{Metode}

Pengabdian yang dilakukan oleh Badan Eksekutif Mahasiswa (BEM) Fakultas Ilmu Budaya Universitas Padjadjaran yang didampingi oleh Taufik Ampera, M. Hum dilakukan secara kolaboratif dengan berbagai pihak yang dapat membantu mewujudkan tujuan pengabdian. Pengabdian dilakukan mulai bulan Juli 2019 sampai dengan Juli 2020. Walaupun harus berhenti sementara karena hambatan wabah virus Korona dan keluarnya kebijakan Physical distancing atau jaga jarak oleh pemerintah.

Metode yang dilakukan adalah pengabdian kolaboratif (collaborative action), pelatihan partisipatif untuk pelestarian kesenian, diskusi naskah dan pemberdayaan ekonomi masyarakat berbasis budaya. Program ini secara umum ditujukan sebagai salah satu sarana pelestarian kebudayaan khususnya bagi situs Kabuyutan Ciburuy. Pelestarian dilakukan melalui pembuatan kawasan wisata budaya. Usaha yang dilakukan salah satunya ialah dengan melakukan kerja sama dengan Paguyuban Mahasiswa Sastra Sunda (Pamass) Universitas Padjadjaran dalam pelatihan aksara sunda dan tari. Kerja sama juga dilaksanakan dengan Departemen Sejarah dan Filologi Unpad untuk mengenalkan situs Kabuyutan Ciburuy melalui riset dan penulisan sejarah Kabuyutan Ciburuy. Kegiatan ini juga berkolaborasi dengan Dinas Pariwisata Kabupaten Garut untuk meningkatkan publikasi mengenai situs Kabuyutan Ciburuy dan melakukan koordinasi dalam pengembangan kawasan situs Kabuyutan Ciburuy. Selain itu juga masyarakat sekitar diajak untuk ikut serta dalam pelestarian situs melalui partisipasi dalam berbagai kegiatan serta sama-sama membangun sentra ekonomi berbasis budaya melalui tersedianya Saung budaya dan penyediaan cenderamata. Kolaborasi aktif dalam bidang ekonomi juga dilakukan dengan menggandeng para pengusaha lokal yang bisa berperan sebagai supplier barang-barang khas Garut dan khas dari Ciburuy sendiri.

Selain kolaborasi, pengabdian juga dilakukan dengan memperhatikan berbagai bidang mulai dari seni, teknologi dan ilmu pengetahuan dari inisiatif masyarakat. Dalam aspek seni, tim melaksanakan pelatihan tari tradisional yang bekerja sama dengan Paguyuban Mahasiswa Sastra Sunda untuk melaksanakan pengajaran baca dan tulis aksara Sunda, pelatihan tari tradisional Sunda berupa Jaipong dan Alat kesenian Gong Renteng, serta pelatihan pencak silat. Pelatihan-pelatihan tersebut diharapkan menjadi sarana pengembangan masyarakat serta menjadi media efektif untuk melakukan pelestarian terhadap kesenian khas sunda.

Lalu dalam aspek teknologi, dilaksanakan pembuatan website dan akun Instagram resmi kabuyutan Ciburuy sebagai sarana publikasi wisata. Diharapkan dapat mempermudah alur publikasi serta mempercepat pengenalan situs melalui media internet. Sedangkan dalam aspek ilmu pengetahuan, naskah-naskah yang berada dalam situs Kabuyutan Ciburuy bukan hanya sebatas berisi kisah-kisah semata, tetapi juga mengandung informasi dan pengetahuan yang dapat dimanfaatkan sebagai pengetahuan lokal masyarakat Ciburuy, seperti pengetahuan mengenai pertanian dalam naskah Kawih Katanian, pengetahuan tentang hubungan manusia dan alam dalam naskah Amanat Galunggung (Darsa, 2012). Dengan kekayaan informasi yang diperoleh dari naskah diharapkan menjadi nilai-nilai luhur masyarakat dan diterapkan dalam kehidupan seharihari.

\section{Hasil \\ Pengajaran Aksara Sunda bagi Masyarakat Ciburuy dan Diskusi Kenaskahan}

Pelaksanaan kegiatan ini berhasil mengenalkan dan membudayakan penggunaan aksara Sunda bagi masyarakat, utamanya anak-anak agar dapat kembali membaca naskahnaskah yang ada di situs Kabuyutan Ciburuy. Adapun teknis kegiatannya ialah dengan melakukan kegiatan belajar mengajar dengan menggunakan metode-metode kreatif dan menarik yang dapat memudahkan pemahaman. Kegiatan pembelajaran aksara Sunda telah dilakukan satu minggu sekali pada hari Sabtu pagi oleh Peguyuban Mahasiswa Sastra Sunda (PAMASS Unpad).

\section{Pelatihan Tari Tradisional Sunda Jaipongan dan Kesenian Gong Renteng}

Program ini membantu melestarikan Tari Jaipongan agar tetap menjadi tari tradisional khas Jawa Barat serta memunculkan kesadaran anak-anak untuk ikut andil dalam pelestarian tari jaipongan. Selain itu kegiatan ini juga menghidupkan kembali kelompok rampak tari di sekitar Ciburuy serta mendorong terselenggarakannya penampilan budaya di sekitar situs Kabuyutan Ciburuy. Tim pengabdian mendatangkan pelatih tari tradisional yang kompeten untuk melatih tari serta dilakukan dalam jangka waktu yang konsisten dan berkelanjutan.

\section{Pelatihan Pengelolaan Website dan akun Instagram}

Kegiatan ini sukses mempromosikan desa wisata budaya dan mempertahankan eksistensi Situs Kabuyutan Ciburuy di dunia maya. Selain itu juga pengelola dapat mengoperasikan website sesuai dengan kebutuhannya. 
Tim pengabdian menghadirkan seseorang yang kompeten dalam pengelolaan website serta memberikan pelatihan secara rutin terhadap pengelola situs. Berikut tautan akun Instagram yang sudah digagas oleh Riki Nawawi seorang Filolog Sunda Universitas Padjadjaran dalam pengelolaan informasi Situs Kabuyutan Ciburuy: (https://instagram.com/kabuyutan_ciburuy)

\section{Pembangunan Saung Budaya}

Kegiatan ini menghadirkan sebuah inkubator kebudayaan yang tidak hanya berperan sebagai pelestari kebudayaan. Tetapi juga berperan sebagai sarana masyarakat untuk meningkatkan taraf perekonomian. Dengan dibangunnya saung budaya, maka telah muncul usaha-usaha masyarakat di bidang cinderamata khas kabuyutan ciburuy dan gunung Cikuray serta menjadi pusat kegiatan perekonomian masyarakat. Badan Eksekutif Mahasiswa (BEM) Fakultas Ilmu Budaya bergotog royong mengadakan etalase untuk menampilkan produk lokal masyarakat.

\section{Pelatihan Bela Diri Pencak Silat}

Pencak silat merupakan bela diri yang bersumber dari Jawa Barat dan diajarkan kepada anak-anak desa pamalayan. Dengan pelatihan, anak-anak Desa Pamalayan dapat menjadi pelaku dan pelestari seni bela diri pencak silat khas Sunda. Selain itu, anak-anak yang sudah menguasai pencak silat ditampilkan di kawasan situs Kabuyutan Ciburuy sebagai daya tarik seni budaya bagi wisatawan. Salah satu program pengabdian Badan Eksekutif Mahasiswa (BEM) Fakultas Ilmu Budaya Unpad adalah mengajarkan anak-anak pencak silat secara rutin sebagai bentuk peningkatan kesadaran dan keterlibatan masyarakat desa dalam memajukan kebudayaan daerah.

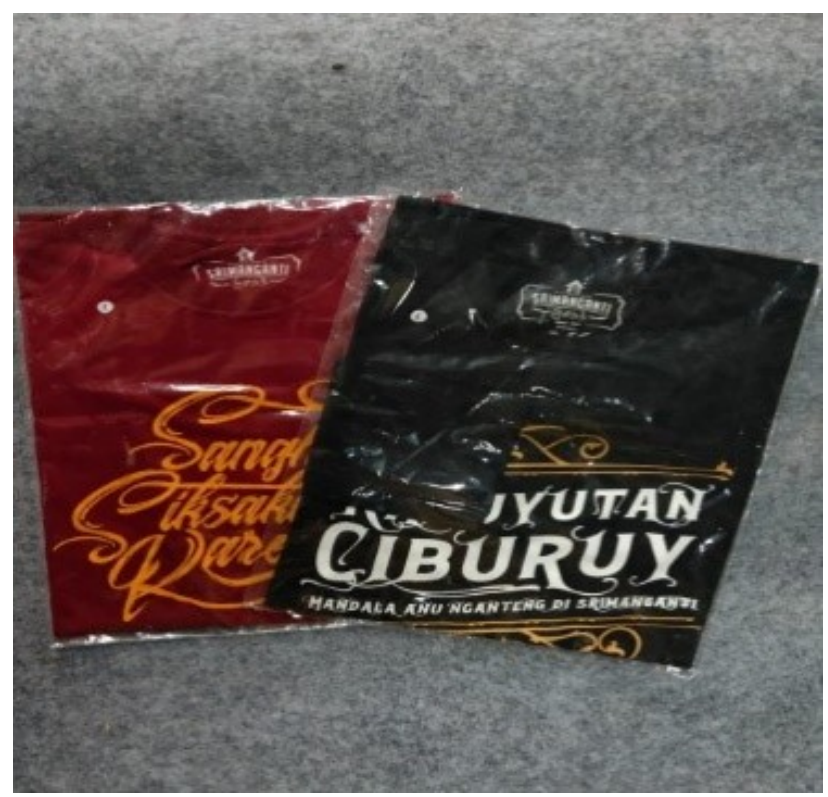

Gambar 1. Kaos khas Kabuyutan Ciburuy yang diproduksi warga sekitar

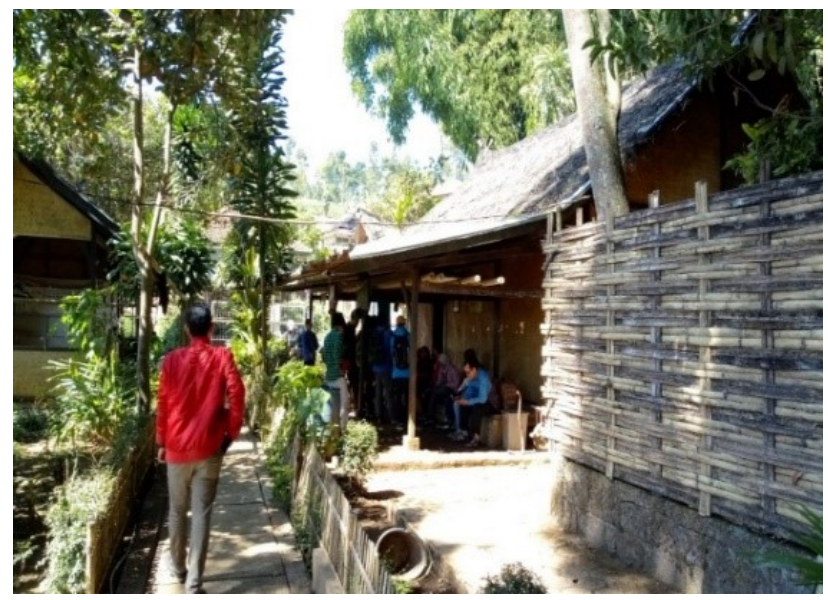

Gambar 2. Kondisi Saung Budaya yang Ramai Dikunjungi

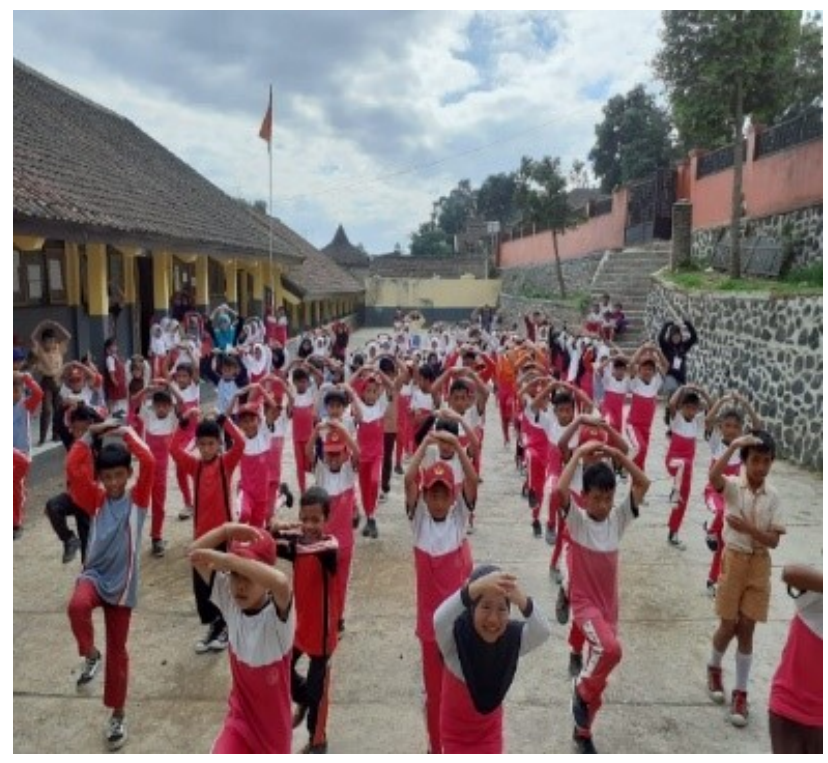

Gambar 3. Pelatihan Pencak Silat di Sekolah Dasar Negeri Sekitar Lokasi

\section{Kesimpulan}

Kegiatan pengabdian yang diinisiasi oleh Badan Eksekutif Mahasiswa (BEM) Fakultas Ilmu Budaya ini dapat menjadi katalisator pengembangan ekonomi berbasis kebudayaan dan pendidikan berbasis kearifan lokal. Kegiatan ini berhasil mendorong berkembangnya ekonomi masyarakat Desa Pamalayan melalui kegiatan ekonomi kreatif, meningkatnya pengetahuan masyarakat Desa Pamalayan di kawasan Situs Kabuyutan Ciburuy, aktifnya kesenian tari tradisional Jaipong dan Gong Renteng yang sudah lama punah hingga terciptanya platform dan web khusus promosi yang efektif sehingga meningkatkan kuantitas pengunjung di Kawasan Situs Kabuyutan Ciburuy. Yang tidak kalah penting juga terbentuknya suasana edukatif bagi kehidupan masyarakat desa Pamalayan. 
Terakhir program pengabdian integratif dan kolaboratif berbasis kebudayaan lokal ini merupakan kegiatan positif yang kedepannya memerlukan dukungan dari semua pihak. Baik pemerintah provinsi Jawa Barat diharapkan dapat mendukung secara finansial. Karena kegiatan ini dilakukan atas kesadaran para mahasiswa dan akademisi untuk mengembangkan kebudayaan daerah. Sedangkan pengelola kegiatan diharapkan dapat memberikan peran partisipasi masyarakat luas dengan cara membuka kesempatan sukarelawan melalui media sosial untuk terlibat dalam kegiatan pengabdian. Hal ini dimaksudkan untuk memberikan dampak yang lebih besar dan meningkatkan publikasi dan kesadaran masyarakat.

\section{Referensi}

Andriyani, A. A. (2017). Pemberdayaan masyarakat melalui pengembangan desa wisata dan Implikasinya Terhadap Ketahanan Sosial budaya Wilayah (Studi Di Desa wisata penglipuran bali). Jurnal Ketahanan Nasional, Vol. 23(1), 1$16 \mathrm{https} / / /$ doi.org/10.22146/jkn.18006.

Darsa, U. A. (2012). Sewaka darma: peti tiga ciburuy garut. Bandung: Pusat Studi Sunda.

Darsa, U. A. (2015). Kodikologi: dinamika identifikasi, inventarisasi dan dokumentasi tradisi pernaskahan Sunda. Bandung: Unpad Press.

Erick Paulus, R. N. (2018). Upaya revitalisasi cagar budaya kabuyutan ciburuy melalui rancang aplikasi bernama mandala. Jurnal Sosioteknologi Vol. 17 No. 1, 39-52.
Hadiwijoyo, S. S. (2012). Perencanaan pariwisata berbasis masyarakat. Yogyakarta: Graha Ilmu.

Hakim, K. K. (2017). Strategi pengembangan wisata budaya (studi kasus pada kawasan situs trowulan sebagai pariwisata unggulan di kabupaten Mojokerto). Jurnal Administrasi Bisnis (JAB). Vol. 41 No. 1, 56-65.

Profil Desa Pamalayan Kecamatan Bayongbong Kabupaten Garut 2019

Rahmatulloh, M. A. (2019). Situs kabuyutan ciburuy: effort sites to preserve local community knowledge (history and cultural approach). International Conference on Research in Social Science and Humanities (p. 2). Frankfurt: Diamond Scientific Publication.

Setiati, A. (2020). Makna tradisi upacara Seba dan implikasi terhadap spiritualitas masyarakat di situs kabuyutan Ciburuy Desa Pamalayan Kecamatan Bayongbong Kabupaten Garut. In A. Setiati, Skripsi. Bandung: Universitas Islam Negeri Sunan Gunung Djati Bandung.

Sukaesih, Y. W. (2016). Preservasi naskah kuno sebagai upaya pembangunan knowledge management (studi kegiatan preservasi naskah kuno sebagai upaya pembangunan knowledge management). Record and Library Journal Vol. 2 (2), 176-187 DOI:10.20473/rlj.v2i2.3059.

Utami, A. R. (2016). Kompetensi khas di sektor pariwisata. Esensi: Jurnal Bisnis dan Manajemen, 75-88 DOI: 10.15408/ess.v6i1.3122. 